Kennesaw State University

DigitalCommons@Kennesaw State University

Faculty Publications

$7-2006$

\title{
Tissue Glycogen and Extracellular Buffering Limit the Survival of Red-Eared Slider Turtles during Anoxic Submergence at $3^{\circ} \mathrm{C}$
}

Daniel E. Warren

Brown University

Scott A. Reese

Kennesaw State University, sreese3@kennesaw.edu

Donald C. Jackson

Brown University

Follow this and additional works at: http://digitalcommons.kennesaw.edu/facpubs

Part of the Animal Sciences Commons, and the Environmental Sciences Commons

\section{Recommended Citation}

Warren DE, Reese SA, Jackson DC. 2006. Tissue glycogen and extracellular buffering limit the survival of red-eared slider turtles during anoxic submergence at $3^{\circ} \mathrm{C}$. Physiological \& Biochemical Zoology 79(4):736-44.

This Article is brought to you for free and open access by DigitalCommons@Kennesaw State University. It has been accepted for inclusion in Faculty Publications by an authorized administrator of DigitalCommons@Kennesaw State University. For more information, please contact

digitalcommons@kennesaw.edu. 


\section{Tissue Glycogen and Extracellular Buffering Limit the Survival of Red-Eared Slider Turtles during Anoxic Submergence at $3^{\circ} \mathrm{C}$}

\author{
Daniel E. Warren ${ }^{\star}$ \\ Scott A. Reese ${ }^{\dagger}$ \\ Donald C. Jackson \\ Department of Molecular Pharmacology, Physiology, and \\ Biotechnology, Brown University, Providence, Rhode Island \\ 02912
}

Accepted 1/10/2006; Electronically Published 5/24/2006

\begin{abstract}
The goal of this study was to identify the factors that limit the survival of the red-eared slider turtle Trachemys scripta during long-term anoxic submergence at $3^{\circ} \mathrm{C}$. We measured blood acid-base status and tissue lactate and glycogen contents after 13, 29, and $44 \mathrm{~d}$ of submergence from ventricle, liver, carapace (lactate only), and four skeletal muscles. We also measured plasma $\mathrm{Ca}^{2+}, \mathrm{Mg}^{2+}, \mathrm{Na}^{+}, \mathrm{K}^{+}, \mathrm{Cl}^{-}$, inorganic phosphate $\left(\mathrm{P}_{\mathrm{i}}\right)$, lactate, and glucose. After $44 \mathrm{~d}$, one of the six remaining turtles died, while the other turtles were in poor condition and suffered from a severe acidemia (blood $\mathrm{pH}=7.09$ from 7.77) caused by lactic acidosis (plasma lactate $91.5 \mathrm{mmol} \mathrm{L}{ }^{-1}$ ). An initial respiratory acidosis attenuated after $28 \mathrm{~d}$. Lactate rose to similar concentrations in ventricle and skeletal muscle (39.3-46.1 $\mu \mathrm{mol}$ $\left.\mathrm{g}^{-1}\right)$. Liver accumulated the least lactate $\left(21.8 \mu \mathrm{mol} \mathrm{g} \mathrm{g}^{-1}\right)$, and carapace accumulated the most lactate $\left(68.9 \mu \mathrm{mol} \mathrm{g}^{-1}\right)$. Plasma $\mathrm{Ca}^{2+}$ and $\mathrm{Mg}^{2+}$ increased significantly throughout submergence to levels comparable to painted turtles at a similar estimated lactate load. Glycogen depletion was extensive in all tissues tested: by $83 \%$ in liver, by $90 \%$ in ventricle, and by $62 \%-88 \%$ in muscle. We estimate that the shell buffered $69.1 \%$ of the total lactate load, which is comparable to painted turtles. Compared with painted turtles, predive tissue glycogen contents and plasma $\mathrm{HCO}_{3}^{-}$concentrations were low. We believe these differences contribute to the poorer tolerance to long-term anoxic submergence in red-eared slider turtles compared with painted turtles.
\end{abstract}

${ }^{*}$ Corresponding author. Present address: Department of Anesthesia, University of California, San Francisco, California 94143; e-mail: warrend@anesthesia.ucsf.edu. ${ }^{\dagger}$ Present address: Department of Biological and Physical Sciences, Kennesaw State University, Kennesaw, Georgia 30144.

Physiological and Biochemical Zoology 79(4):736-744. 2006. (C) 2006 by The University of Chicago. All rights reserved. 1522-2152/2006/7904-5113\$15.00

\section{Introduction}

For most animals, tolerance to hypoxia or anoxia is determined by their ability to downregulate metabolism, maintain and utilize stored glycogen, and manage the end products of anaerobic metabolism, principally lactate and $\mathrm{H}^{+}$(Hochachka 1986; Jackson 2002). Freshwater turtles are extreme examples of anoxiatolerant animals, and the western painted turtle Chrysemys picta, in particular, can survive from 3 to $6 \mathrm{mo}$ at $3^{\circ} \mathrm{C}$ without oxygen (Jackson 2000b). Painted turtles dramatically reduce their metabolic rates, utilize extremely high tissue glycogen contents, and exploit their large skeleton to buffer lactic acid during anoxic submergence. These traits allow the painted turtle to survive winters trapped in ice-covered ponds that may become severely hypoxic or anoxic.

A closely related species, the red-eared slider Trachemys scripta, is found in habitats that are similar in most respects to that of the painted turtle except that they are found in regions of the country that do not routinely freeze during winter months (Conant and Collins 1998). One might expect, therefore, that these turtles cannot tolerate periods of anoxic submergence to the same extent as painted turtles. Indeed, it has been shown that adult red-eared slider turtles can survive anoxic submergence at $3^{\circ} \mathrm{C}$ for only $25-41 \mathrm{~d}$ (Ultsch 1985).

We hypothesized that the poorer tolerance of the red-eared slider could be due to the deficiencies in one or more of the traits contributing to anoxia tolerance in the painted turtle. Our objective in this study, therefore, was to perform a comprehensive analysis of the slider turtle's response to anoxic submergence at $3^{\circ} \mathrm{C}$, including blood ionic and acid-base status, tissue lactate and glycogen contents, and the contributions of the shell to the buffering of lactic acid. Our results indicate that glycogen depletion and low predive $\mathrm{HCO}_{3}^{-}$are major factors limiting anoxic survival in this species.

\section{Material and Methods}

Animals

Red-eared slider turtles Trachemys scripta elegans (Wied 1839; $N=30$; body mass $=492.8-853.4 \mathrm{~g}$ ) were obtained from Lemberger (Oshkosh, WI) and maintained at Brown University under a $12 \mathrm{~L}: 12 \mathrm{D}$ photoperiod at temperatures ranging from $20^{\circ}$ to $25^{\circ} \mathrm{C}$ with access to clean Providence tap water, heating 
Table 1: Blood $\mathrm{pH}, \mathrm{PO}_{2}$, and $\mathrm{PCO}_{2}$ and plasma $\mathrm{HCO}_{3}^{-}$during anoxic submergence and in unsubmerged controls

\begin{tabular}{|c|c|c|c|c|c|}
\hline & $\begin{array}{l}\text { Blood } \mathrm{Po}_{2} \\
(\mathrm{mmHg})\end{array}$ & $\begin{array}{l}\text { Blood } \mathrm{PCO}_{2} \\
(\mathrm{mmHg})\end{array}$ & Blood pH & $\begin{array}{l}\text { Plasma } \mathrm{HCO}_{3}^{-} \\
\left(\text {meq L L }{ }^{-1}\right)\end{array}$ & $\begin{array}{l}\text { Hematocrit } \\
(\%)\end{array}$ \\
\hline Presubmergence controls & $39.9 \pm 9.2^{\mathrm{A}}$ & $11.6 \pm .3^{\mathrm{A}}$ & $7.77 \pm .03^{\mathrm{A}}$ & $24.80 \pm 1.51^{\mathrm{A}}$ & $23.5 \pm 2.3$ \\
\hline$N$ & 5 & 5 & 5 & 5 & 6 \\
\hline 13-d submergence & $.6 \pm .2^{\mathrm{B}}$ & $19.6 \pm 1.1^{\mathrm{B}}$ & $7.35 \pm .04^{\mathrm{B}}$ & $16.03 \pm 1.30^{\mathrm{B}}$ & $25.7 \pm 3.2$ \\
\hline$N$ & 6 & 6 & 6 & 6 & 6 \\
\hline 29-d submergence & $.0 \pm .0^{\mathrm{B}}$ & $15.5 \pm 1.5^{\mathrm{C}}$ & $7.24 \pm .03^{\mathrm{C}}$ & $10.23 \pm 1.58^{\mathrm{C}}$ & $29.5 \pm 2.0$ \\
\hline$N$ & 6 & 6 & 6 & 6 & 6 \\
\hline 44-d submergence & $.0 \pm .0^{\mathrm{B}}$ & $15.2 \pm 1.5^{\mathrm{C}}$ & $7.09 \pm .03^{\mathrm{D}}$ & $7.04 \pm .97^{\mathrm{C}}$ & $29.3 \pm 4.0$ \\
\hline$N$ & 5 & 5 & 5 & 5 & 5 \\
\hline 46-d controls & $45.9 \pm 7.8^{\mathrm{A}}$ & $15.8 \pm .5^{\mathrm{C}}$ & $7.73 \pm .02^{\mathrm{A}}$ & $30.52 \pm 1.02^{\mathrm{D}}$ & $29.1 \pm 2.1$ \\
\hline$N$ & 5 & 5 & 5 & 5 & 5 \\
\hline
\end{tabular}

Note. Values are means \pm SEM. Different letters indicate significant differences between groups for a parameter (one-factor ANOVA; Student's $t$-test; $P<0.05)$.

lamps, and a warming platform for $1-2 \mathrm{wk}$. The conditions under which the turtles were held before arriving in Providence were not known, but the turtles all appeared healthy and behaved normally. The turtles were moved to a $3^{\circ} \mathrm{C}$ cold room, where they were placed in a large plastic tank $(42 \mathrm{~cm} \times 77$ $\mathrm{cm} \times 137 \mathrm{~cm}$ ) with $\sim 25 \mathrm{~cm}$ of water maintained at $15^{\circ} \mathrm{C}$ by a temperature controller. Water temperature was lowered $2^{\circ} \mathrm{C}$ daily until it reached $3^{\circ} \mathrm{C}$ after $6 \mathrm{~d}$. Turtles were not fed during the course of the acclimation. Experiments were completed during the months of March and April. The experimental protocol used in this study was approved by the Brown University Institutional Animal Care and Use Committee (IACUC 25-05).

\section{Presubmergence Control Sampling}

All sampling was performed in a $3^{\circ} \mathrm{C}$ cold room. Control turtles $(N=6)$ were sampled the day before the start of submergence. The turtles were quickly decapitated after their necks were clamped, and their plastrons were quickly removed with a bone saw. A 1.0-mL blood sample was drawn into a glass syringe via cardiac puncture and analyzed for blood $\mathrm{PCO}_{2}, \mathrm{Po}_{2}, \mathrm{pH}$, and hematocrit and for plasma lactate, glucose, $\mathrm{Ca}^{2+}, \mathrm{Mg}^{2+}, \mathrm{Na}^{+}$, $\mathrm{K}^{+}, \mathrm{Cl}^{-}$, and inorganic phosphate $\left(\mathrm{P}_{\mathrm{i}}\right)$, as described below. The following tissues were quickly sampled and flash frozen with clamps cooled in liquid nitrogen: ventricle, liver, and pectoralis, retrahens capitis, flexor digitorum longus, and iliofibularis muscles. These samples were stored at $-75^{\circ} \mathrm{C}$ until analyzed for lactate, glucose, and glycogen contents, as described below. Carapace was sampled and frozen at $-20^{\circ} \mathrm{C}$ until analyzed for lactate, also described below.

\section{Submergence}

Acclimated turtles $(N=18$ total) were transferred to a large fiberglass tank $(46 \mathrm{~cm} \times 46 \mathrm{~cm} \times 60 \mathrm{~cm}, \mathrm{H} \times \mathrm{W} \times \mathrm{L})$ containing $\sim 40 \mathrm{~cm}$ water $(\sim 108 \mathrm{~L})$ and two large bubbling strips. Water temperature was $3^{\circ} \mathrm{C}$. Nitrogen gas was bubbled continuously throughout the duration of the submergence. A plastic grating was placed over the surface of the water to prevent access to the gas space above while still allowing nitrogen gas to escape. An acrylic lid was sealed over the top of the tank and the tubing threaded out through a small hole in the lid. Turtles were sampled after $13(N=6), 29(N=6)$, and $44 \mathrm{~d}$ $(N=5)$, as described above, except that their necks were clamped underwater. One turtle was found dead after $44 \mathrm{~d}$, the data from which are not reported.

Table 2: Plasma ion concentrations during anoxic submergence and in unsubmerged controls

\begin{tabular}{lllllrll}
\hline & $N$ & {$\left[\mathrm{Na}^{+}\right]$} & {$\left[\mathrm{K}^{+}\right]$} & {$\left[\mathrm{Cl}^{-}\right]$} & {$\left[\mathrm{Ca}^{2+}\right]$} & {$\left[\mathrm{Mg}^{2+}\right]$} & {$\left[\mathrm{P}_{\mathrm{i}}\right]$} \\
\hline Presubmergence controls & 6 & $118.6 \pm 1.5^{\mathrm{A}}$ & $2.8 \pm .1^{\mathrm{A}}$ & $95.2 \pm 2.0^{\mathrm{A}}$ & $1.9 \pm .1^{\mathrm{A}}$ & $1.6 \pm .1^{\mathrm{A}}$ & $.51 \pm .02$ \\
13-d submergence & 6 & $115.2 \pm 3.3^{\mathrm{AB}}$ & $4.2 \pm .2^{\mathrm{B}}$ & $79.7 \pm 2.8^{\mathrm{B}}$ & $5.6 \pm .5^{\mathrm{B}}$ & $3.7 \pm .3^{\mathrm{B}}$ & $.56 \pm .08$ \\
29-d submergence & 6 & $107.3 \pm 2.7^{\mathrm{C}}$ & $5.8 \pm .3^{\mathrm{C}}$ & $72.1 \pm 2.0^{\mathrm{C}}$ & $10.3 \pm 1.0^{\mathrm{C}}$ & $5.4 \pm .5^{\mathrm{C}}$ & $.47 \pm .06$ \\
44-d submergence & 5 & $102.1 \pm 2.5^{\mathrm{C}}$ & $5.9 \pm .3^{\mathrm{C}}$ & $64.5 \pm 4.3^{\mathrm{C}}$ & $17.4 \pm 1.8^{\mathrm{D}}$ & $6.8 \pm .4^{\mathrm{D}}$ & $.56 \pm .08$ \\
46-d controls & 5 & $108.6 \pm 2.8^{\mathrm{BC}}$ & $3.0 \pm .2^{\mathrm{A}}$ & $84.6 \pm 1.5^{\mathrm{B}}$ & $2.4 \pm .1^{\mathrm{A}}$ & $2.0 \pm .1^{\mathrm{A}} .45 \pm .04$ \\
\hline
\end{tabular}

Note. Values are means \pm SEM. Units are $\mathrm{mmol} \mathrm{L}^{-1}$ plasma. Different letters indicate significant differences between groups for each ion (onefactor ANOVA; Student's $t$-test; $P<0.05$ ). 
Table 3: Tissue glucose concentrations during anoxic submergence and in unsubmerged controls

\begin{tabular}{|c|c|c|c|c|c|c|c|c|}
\hline & \multirow[b]{2}{*}{ Plasma } & \multirow[b]{2}{*}{ Ventricle } & \multirow[b]{2}{*}{ Liver } & & \multicolumn{4}{|l|}{ Muscle } \\
\hline & & & & & $\begin{array}{l}\text { Flexor } \\
\text { Digitorum } \\
\text { Longus }\end{array}$ & Iliofibularis & $\begin{array}{l}\text { Retrahens } \\
\text { Capitis }\end{array}$ & Pectoralis \\
\hline Presubmergence controls & $1.98 \pm .34^{\mathrm{A}}$ & $4.15 \pm 1.33$ & 10.79 & $\pm 1.41^{\mathrm{A}}$ & $.96 \pm .38$ & $1.19 \pm .53$ & $.90 \pm .11^{\mathrm{A}}$ & $1.79 \pm 1.19$ \\
\hline$N$ & 6 & 6 & & 6 & 6 & 6 & 6 & 5 \\
\hline 13-d submergence & $8.03 \pm 2.59^{\mathrm{B}}$ & $1.84 \pm .49$ & 5.34 & $\pm 1.35^{\mathrm{B}}$ & $1.60 \pm .49$ & $3.49 \pm 1.03$ & $4.22 \pm 1.32^{\mathrm{BC}}$ & $3.88 \pm .78$ \\
\hline$N$ & 6 & 6 & & 6 & 6 & 6 & 6 & 6 \\
\hline 29-d submergence & $9.35 \pm 2.93^{\mathrm{B}}$ & $.62 \pm .32$ & 5.13 & $\pm .81^{\mathrm{B}}$ & $.49 \pm .23$ & $3.56 \pm 1.02$ & $5.81 \pm 1.51^{\mathrm{C}}$ & $3.11 \pm .91$ \\
\hline$N$ & 6 & 6 & & 6 & 4 & 6 & 6 & 6 \\
\hline 44-d submergence & $7.16 \pm 1.58^{\mathrm{AB}}$ & $1.11 \pm .42$ & 2.09 & $\pm .64^{\mathrm{B}}$ & $1.81 \pm 1.38$ & $3.48 \pm 1.14$ & $4.51 \pm 1.11^{\mathrm{C}}$ & $3.22 \pm .71$ \\
\hline$N$ & 5 & 5 & & 5 & 4 & 5 & 5 & 5 \\
\hline 46-d controls & $1.56 \pm .49^{\mathrm{A}}$ & $3.24 \pm 1.69$ & 11.4 & $\pm 2.00^{\mathrm{A}}$ & $1.41 \pm .56$ & $1.06 \pm .26$ & $1.13 \pm .20^{\mathrm{AB}}$ & $.93 \pm .34$ \\
\hline$N$ & 5 & 5 & & 5 & 4 & 5 & 5 & 5 \\
\hline
\end{tabular}

Note. Values are means \pm SEM. Units are $\mu$ mol glucose $\mathrm{g}^{-1}$ plasma or tissue. Different letters indicate significant differences between times for a tissue (onefactor ANOVA; Student's $t$-test; $P<0.05$ ).

\section{Postsubmergence Control Sampling}

A second group of control turtles $(N=5)$ that were held at $3^{\circ} \mathrm{C}$ with access to air were sampled $2 \mathrm{~d}$ after the final submergence sample, as described above. A sixth turtle was sampled, but we did not include it in our analysis because of its poor physical condition in comparison to the others, all of which appeared healthy.

\section{Blood Analysis}

Blood $\mathrm{PCO}_{2}$ and $\mathrm{PO}_{2}$ were analyzed on $0.3 \mathrm{~mL}$ of blood using a Radiometer PHM73 pH/blood gas monitor and BMS3 Mk2 Blood Microsystem (Radiometer, Copenhagen, Denmark) thermostated to $3^{\circ} \mathrm{C}$. The remainder $(\sim 0.7 \mathrm{~mL})$ was injected through a $4-\mathrm{cm}$ segment of Intramedic PE60 into the bottom of a 10 -mm-diameter round-bottom test tube containing an Orion $\mathrm{pH}$ electrode (8103BN, Thermo Orion, Beverly, MA) with a $6.3-\mathrm{mm}$ diameter. With the blood sample, PE tubing, and $\mathrm{pH}$ electrode in the tube, the surface area for gas exchange was limited to $46.2 \mathrm{~mm}^{2}$, with $58 \mathrm{~mm}$ between the air : blood interface and the opening of the tube. The $\mathrm{pH}$ electrode and test tube were thermostated to the temperature of the BMS3 Mk2 by storing them in one of its ampoule wells before and during each measurement. This technique is similar to one used in a previous study (Jackson et al. 2000) and gives $\mathrm{pH}$ values comparable to those using other methods. Plasma bicarbonate was calculated using the Henderson-Hasselbach equation with $\mathrm{pK}^{\prime}=6.35$ (Jackson and Heisler 1983) and $\alpha \mathrm{CO}_{2}=0.0812$ (Reeves 1976). The blood was centrifuged at 9,300 $g$ for $3 \mathrm{~min}$, and the plasma was analyzed for lactate and glucose using an automated analyzer (2300 Stat, YSI, Yellow Springs, OH), $\mathrm{Ca}^{2+}$ and $\mathrm{Mg}^{2}$ using atomic absorption spectrophotometry (PerkinElmer, Boston), $\mathrm{Na}^{+}$and $\mathrm{K}^{+}$using flame photometry (IL 943, Instrumentation Laboratories, Lexington, $\mathrm{MA}$ ), and $\mathrm{Cl}^{-}$and $\mathrm{P}_{\mathrm{i}}$ using standard kits (Chloride Liquicolor, Stanbio Laboratory, Boerne, TX; Kit 670, Sigma, St. Louis).

\section{Tissue Analysis}

Frozen samples of all soft tissues (100-200 mg) were homogenized in $1 \mathrm{~mL}$ ice-cold $0.6 \mathrm{~N}$ perchloric acid using a MiniBeadbeater 3110BX (Biospec Products, Bartlesville, OK) with 1 -mm glass beads for $4 \mathrm{~min}$ at maximum speed. A $150-\mu \mathrm{L}$ sample of this homogenate was buffered with $75 \mu \mathrm{L} 1 \mathrm{M}$ $\mathrm{KHCO}_{3}$, centrifuged for $3 \mathrm{~min}$ at $9,300 \mathrm{~g}$, and analyzed for glucose and lactate using standard kits (glucose assay reagent, Sigma; lactate reagent, Trinity Biotech, St. Louis). A 50- $\mu \mathrm{L}$ sample of the homogenate was buffered with $25 \mu \mathrm{L} 1 \mathrm{M} \mathrm{KHCO}_{3}$ and analyzed for glycogen using the amyloglucosidase method of Keppler and Decker (1974). This homogenate was analyzed for glucose using the glucose kit. The tissue glycogen content was calculated as the difference between the glucose content after glycogen hydrolysis and the free glucose content from the tissue homogenate.

Frozen carapace $(\sim 1 \mathrm{~g})$ was pulverized to a powder under liquid nitrogen (Spex 6700 Freezer Mill). The powder was incubated in 5 vol of $0.6 \mathrm{~N}$ perchloric acid for $2 \mathrm{~h}$, vortexing everything $15 \mathrm{~min}$. A sample of this homogenate was centrifuged at 9,300 g, and lactate was measured on the supernatant using a standard kit (lactate reagent, Trinity Biotech).

\section{Statistical Analysis}

One-factor ANOVA was used to determine whether any of the parameters differed between groups of submerged and control turtles. Student's $t$-tests were used post hoc to elucidate any significant effect. The significance level was $P<0.05$. All statistical computations were carried out using JMP 5.0 (SAS Institute, Cary, NC). 

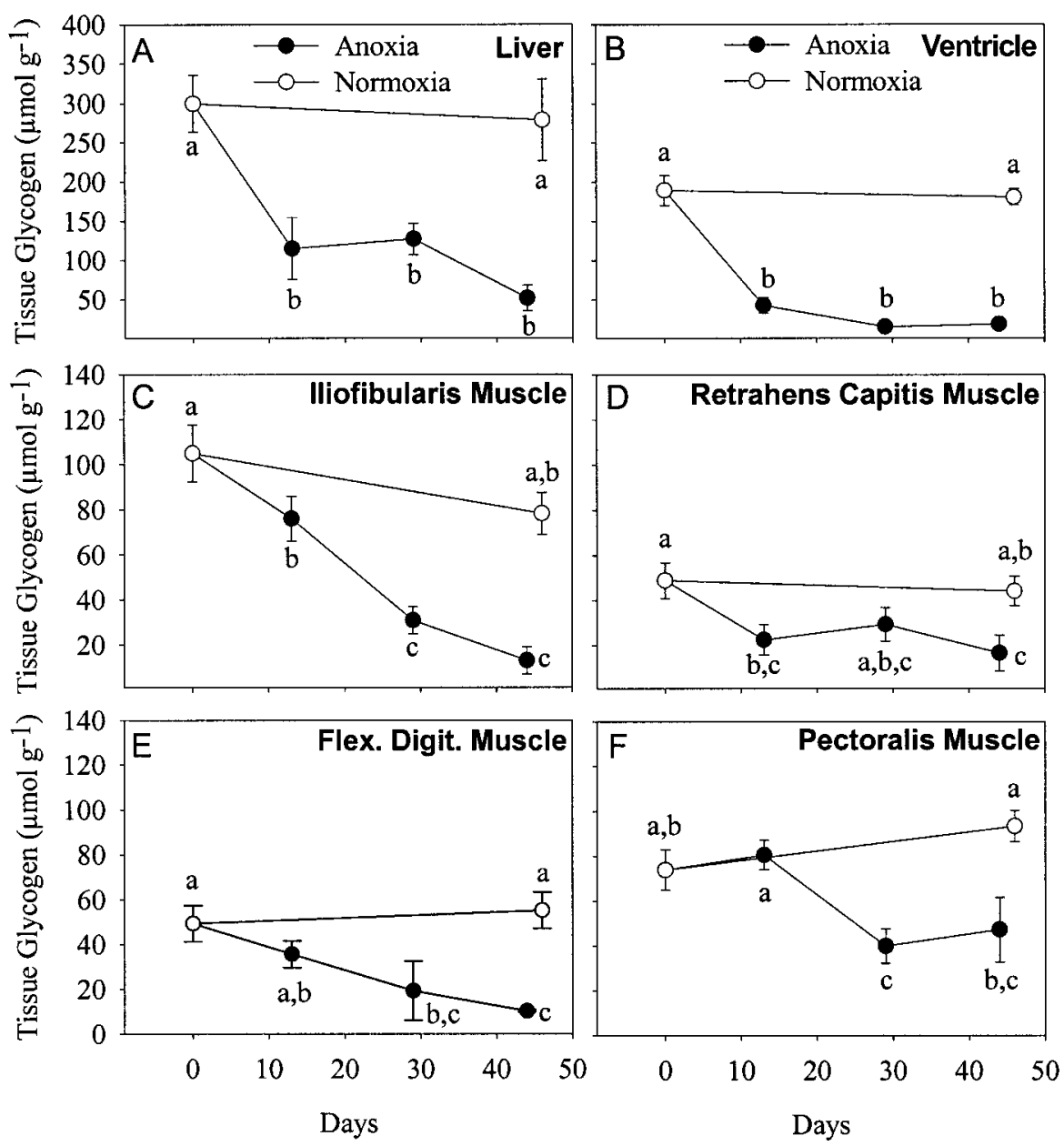

Figure 1. Tissue glycogen contents in red-eared slider turtles during $44 \mathrm{~d}$ of anoxic submergence or in normoxic control turtles at $3^{\circ} \mathrm{C}$. Values are means \pm SEM for each tissue. $A$, Liver. $B$, Ventricle. $C$, Iliofibularis muscle. $D$, Retrahens capitis muscle. $E$, Flexor digitorum longus muscle. $F$, Pectoralis muscle. Different letters indicate significant differences between groups of turtles across treatments for each tissue (one-factor ANOVA; Student's $t$-tests, $P<0.05 ; N$ values are the same as in Table 3 ).

\section{Results}

\section{General Condition of the Animals}

All submerged turtles, other than those sampled, survived 29 $\mathrm{d}$ of anoxia, but only five of the six remaining animals were alive after $44 \mathrm{~d}$, and they were in poor condition. The normoxic control animals at $46 \mathrm{~d}$ appeared healthy and strong except for one turtle that appeared weak and swollen. This animal was excluded from the data analysis.

\section{Blood Acid-Base Status}

The changes in blood acid-base status during $44 \mathrm{~d}$ of anoxic submergence at $3^{\circ} \mathrm{C}$ are summarized in Table 1 . The submergence caused an initial increase in blood $\mathrm{PCO}_{2}$, indicating a respiratory acidosis, which attenuated by $29 \mathrm{~d}$ and did not change thereafter or differ from 46-d controls. Blood $\mathrm{PCO}_{2}$ increased slightly but significantly after $46 \mathrm{~d}$ in control turtles. Submergence also caused a severe metabolic acidosis, as indicated by reduced plasma $\mathrm{HCO}_{3}^{-}$, and increased plasma lactate (Fig. 2). Together, these acidoses contributed to a severe acidemia. Plasma $\mathrm{HCO}_{3}^{-}$after $46 \mathrm{~d}$ was significantly higher than at time 0 in control turtles. Blood $\mathrm{Po}_{2}$ was $<1.0 \mathrm{mmHg}$ throughout the submergence, reflecting the anoxia. Blood $\mathrm{PO}_{2}$ and $\mathrm{pH}$ were unchanged in control turtles after $46 \mathrm{~d}$. Hematocrit was unaffected by submergence or $46 \mathrm{~d}$ of normoxia.

\section{Plasma Ion Concentrations}

The effects of $44 \mathrm{~d}$ of anoxic submergence at $3^{\circ} \mathrm{C}$ on plasma ion concentrations are summarized in Table 2. Plasma $\mathrm{Na}^{+}$ decreased steadily throughout the experiment in both submerged and control groups. Plasma $\mathrm{Cl}^{-}$decreased in both sub- 

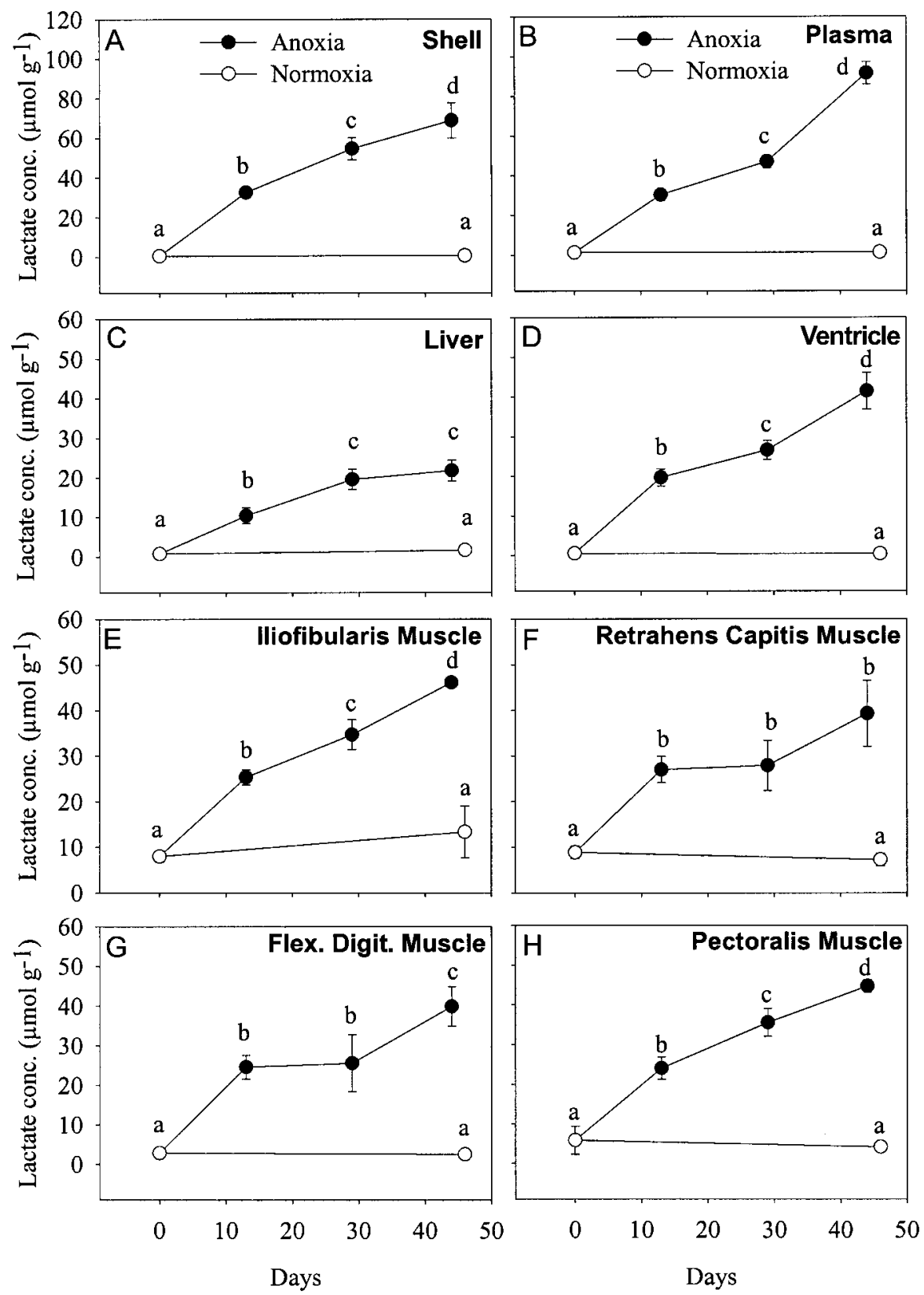

Figure 2. Tissue lactate contents in red-eared slider turtles during $44 \mathrm{~d}$ of anoxic submergence or in normoxic control turtles at $3^{\circ} \mathrm{C}$. Values are means \pm SEM for each tissue. A, Shell. B, Plasma. $C$, Liver. D, Ventricle. E, Iliofibularis muscle. F, Retrahens capitis muscle. $G$, Flexor digitorum longus muscle. $H$, Pectoralis muscle. Different letters indicate significant differences between groups of turtles across treatments for each tissue (one-factor ANOVA; Student's $t$-tests, $P<0.05 ; N$ values are the same as in Table 3 ).

merged and control animals but did so more rapidly in submerged animals. Plasma $\mathrm{Ca}^{2+}, \mathrm{Mg}^{2+}$, and $\mathrm{K}^{+}$increased significantly in submerged animals but did not change in controls. Neither submergence nor $46 \mathrm{~d}$ of normoxia affected plasma $\mathrm{P}_{\mathrm{i}}$.
Tissue Glucose and Glycogen Contents

Glucose concentrations (Table 3) changed significantly during submergence only in liver, where it decreased, and in plasma and retrahens capitis muscle, where it increased. The elevation 
Table 4: Comparison of skeletal buffering contributions in Trachemys scripta and Chrysemys picta bellii during anoxic submergence at $3^{\circ} \mathrm{C}$

\begin{tabular}{|c|c|c|c|c|c|c|}
\hline Species & $\begin{array}{l}\text { Days } \\
\text { Submerged }\end{array}$ & $\begin{array}{l}\text { Estimated } \\
\text { Lactate Load } \\
\left(\mathrm{mmol} \mathrm{kg}^{-1}\right)\end{array}$ & $\begin{array}{l}\text { Lactate Load } \\
\text { in Shell }+ \\
\text { Skeleton }(\%)\end{array}$ & $\begin{array}{l}\Delta \text { Plasma }\left[\mathrm{Mg}^{2+}\right] / \\
\text { Lactate Load }\end{array}$ & $\begin{array}{l}\Delta \text { Plasma }\left[\mathrm{Ca}^{2+}\right] / \\
\text { Lactate Load }\end{array}$ & $\begin{array}{l}\Delta \text { Plasma } \mathrm{pH} / \\
\text { Lactate Load }\end{array}$ \\
\hline Trachemys scripta & 44 & 50.33 & 52.7 & .103 & .308 & .0135 \\
\hline Chrysemys picta belli & 50 & $49.3^{\mathrm{a}}$ & $38.9^{\mathrm{b}}$ & $.146^{\mathrm{a}}$ & $.257^{\mathrm{a}}$ & $.010^{\mathrm{a}}$ \\
\hline
\end{tabular}

${ }^{a}$ Estimates made using data from Reese et al. (2004).

${ }^{\mathrm{b}}$ Estimates made using data from Jackson et al. (2000).

in plasma glucose was maintained through $29 \mathrm{~d}$ but decreased thereafter until it was no longer significantly different from controls at $44 \mathrm{~d}$. Tissue glucose in retrahens capitis muscle increased up to $29 \mathrm{~d}$ and remained elevated throughout submergence. Tissue glucose did not change in the control turtles.

The changes in tissue glycogen during the experiment are summarized in Figure 1. All of the tissues examined were depleted of glycogen after $44 \mathrm{~d}$ of anoxic submergence. Ventricular glycogen depletion was rapid and nearly complete by $13 \mathrm{~d}$. Liver glycogen also fell quickly but did not approach complete depletion until $44 \mathrm{~d}$. All muscles except pectoralis depleted their glycogen steadily and were near complete depletion by $44 \mathrm{~d}$. Pectoralis glycogen did not decrease until $29 \mathrm{~d}$. The $46-\mathrm{d}$ control animals showed no significant change in tissue glycogen, although iliofibularis and retrahens capitis tended to decrease.

\section{Tissue Lactate Accumulation}

Tissue lactate accumulation during the experiment is summarized in Figure 2. Lactate increased steadily in all tissues and reached its highest concentrations in shell and plasma. Liver accumulated the least lactate, while the four skeletal muscles and ventricle accumulated similar amounts. Control turtles did not accumulate lactate in their tissues after $46 \mathrm{~d}$.

\section{Discussion}

The poor condition of the turtles after $44 \mathrm{~d}$ is consistent with a previous study of red-eared slider turtles (Ultsch 1985), in which a cohort of eight turtles died between 25 and $41 \mathrm{~d}$ of anoxic submergence at $3^{\circ} \mathrm{C}$. Because the turtles in our study were so close to their tolerance limit, we view this as an opportunity to gain insight into the factors that limit the survival of this species during anoxic submergence. Three factors are believed to determine this limit (Hochachka 1986; Jackson 2002): (1) the ability to reduce metabolic rate, (2) the animal's capacity to buffer lactic acid, and (3) the size of the tissue glycogen stores. We discuss each of these factors in the context of this experiment and compare and contrast, qualitatively, the responses of red-eared slider turtle to long-term anoxia to those of the more anoxia-tolerant painted turtle.

Metabolic rate reduction can be assessed by assuming that lactate is the final end product of anaerobic ATP production and is not excreted in the urine. Its accumulation rate in the animal would therefore be proportional to the animal's metabolic rate. In this study, tissue lactate accumulation rates generally mirrored that of plasma, indicating that plasma lactate accumulation is an adequate proxy for metabolic rate. By 44 $\mathrm{d}$, the plasma lactate concentrations in this study $\left(91.5 \mathrm{mmol}^{-1}\right)$ were slightly greater than those after $50 \mathrm{~d}$ in western painted turtle (Chrysemys picta bellii; $89.7 \mathrm{mmol} \mathrm{L}^{-1}$; Reese et al. 2004) but were less than in the midland painted turtle (Chrysemys picta marginata; ca. $105 \mathrm{mmol} \mathrm{L}^{-1}$; Reese et al. 2000), also after $50 \mathrm{~d}$. These two painted turtle subspecies have been shown to survive $150 \mathrm{~d}$ of anoxic submergence (Ultsch 1985; Reese et al. 2000). Although an even more exaggerated metabolic depression would likely extend the red-eared slider's tolerance to anoxia, the similarity between the anaerobic metabolic rates of the two species indicates that some other factor is primarily limiting.

The ability of turtles to buffer lactic acid with bone is believed to be an important determinant of their anoxia tolerance (Jackson $2000 a$ ). We estimated and compared the contributions of shell and skeleton to the buffering of the lactate load for the red-eared slider and compared them with the same estimates for painted turtles using data from a previous study (Table 4). We assumed similar organ weights for the two species (liver $6 \%$; small intestine 3\%; shell and skeleton 39\%; muscle $20 \%$; ventricle $0.2 \%$; blood $8 \%$; and kidneys, reproductive organs, lung, and peritoneal and cerebrospinal fluids balance, collectively, 23.8\%; D. E. Warren and D. C. Jackson, unpublished data) and that the lactate contents of unsampled tissues were

Table 5: Comparison of the changes in $\left[\mathrm{H}^{+}\right]$relative to plasma lactate in Trachemys scripta and Chrysemys picta bellii during anoxic submergence at $3^{\circ} \mathrm{C}$

\begin{tabular}{lcl}
\hline & & $\begin{array}{l}\Delta \text { Plasma }\left[\mathrm{H}^{+}\right] \\
\left(\mathrm{mmol} \mathrm{L}^{-1}\right) /\end{array}$ \\
Species & $\begin{array}{l}\text { Days } \\
\text { Submerged }\end{array}$ & $\begin{array}{l}\Delta \text { Plasma [Lactate] } \\
\left(\mathrm{mmol} \mathrm{L}^{-1}\right)\end{array}$ \\
\hline Trachemys scripta & 44 & $7.12 \times 10^{-10}$ \\
Chrysemys picta belli & 50 & $6.26 \times 10^{-10}$ \\
\hline
\end{tabular}

Note. Chrysemys picta belli are estimates made using data from Jackson et al. (2000). 
similar to that of plasma. Although red-eared slider turtles release comparable $\mathrm{Ca}^{2+}$ and $\mathrm{Mg}^{2+}$ carbonates from bone into the extracellular fluid, they sequester a greater fraction of the lactate load in bone after $44 \mathrm{~d}$ than painted turtles do after 50 d. Therefore, we conclude that the buffering contribution by shell was not a primary factor limiting survival of red-eared slider turtles during long-term anoxic submergence. Instead, for reasons given below, the skeleton probably extended the anoxic dive time of red-eared slider turtles.

Despite the large buffer contribution from bone, acidosis was likely a major contributor to the impending metabolic failure in this study. Changes in blood $\mathrm{pH}$ have been shown to track changes in intracellular $\mathrm{pH}$ during $12 \mathrm{wk}$ of anoxic submergence at $3^{\circ} \mathrm{C}$ in painted turtles (Jackson and Heisler 1983), and so blood $\mathrm{pH}$ measurements in this experiment are likely to reflect the acid-base status of the intracellular space. The acidemia after $44 \mathrm{~d}$ in slider turtles was qualitatively more severe than in western painted turtles after $50 \mathrm{~d}$ from a previous study (Tables 4,5 ) but was similar to that of painted turtles just before death after 6 mo of anoxia (Ultsch and Jackson 1982). The blood $\mathrm{pH}$ of the sliders reached this lower and probably critical point more quickly because their blood $\mathrm{pH}$ and extracellular $\mathrm{HCO}_{3}^{-}$concentration were low at the start of the submergence period. Blood $\mathrm{pH}$ before submergence was 7.77 in slider turtles in this study but has been shown to be equal to or greater than 8.00 in normoxic painted turtles at the same temperature (Jackson and Heisler 1983; Herbert and Jackson 1985; Jackson et al. 2000; Reese et al. 2004). Plasma $\mathrm{HCO}_{3}^{-}$concentration in this study was only slightly more than half of that observed in painted turtles at a similar temperature (24.8 vs. 39.4-48.8 meq L ${ }^{-1}$; Jackson and Heisler 1983; Herbert and Jackson 1985; Jackson et al. 2000; Reese et al. 2004) and accounts for the lower resting blood $\mathrm{pH}$ in slider turtles. By $44 \mathrm{~d}$ into the submergence, arterial $\mathrm{PCO}_{2}$ was similar to that in painted turtles and did not differ from controls.

The severity of the acidosis incurred by the anoxic slider turtles shows that a high skeletal contribution to buffering cannot fully counteract the acid-base limitations imposed by low extracellular $\mathrm{HCO}_{3}^{-}$before submergence. The buffering of lactic acid by shell, however, was probably important in extending dive time significantly, which becomes apparent if one assumes that $\mathrm{HCO}_{3}^{-}$is the principal extracellular buffer and that $\mathrm{H}^{+}$ enters the extracellular fluid with a lactate anion in equal molarities. On the basis of the lactate production rates observed in this study, we estimate that the entire extracellular $\mathrm{HCO}_{3}^{-}$ pool would have been consumed in less than $11 \mathrm{~d}$ if extracellular $\mathrm{HCO}_{3}^{-}$were the principal buffer.

Exhaustion of tissue glycogen reserves, in particular those in liver, probably contributed to the reduced tolerance of redeared slider turtles to anoxic submergence. The near depletion of tissue glycogen stores after $44 \mathrm{~d}$ was correlated with a decline in plasma glucose. Tissue glucose was maintained at the end of the submergence presumably through influx from the ex- tracellular space, which in turn maintained the glycolytic flux and subsequent lactate production. Although the absolute depletion in liver glycogen after $29 \mathrm{~d}\left(172.2 \mu \mathrm{mol} \mathrm{g}^{-1}\right)$ in this study was less than in painted turtles after $28 \mathrm{~d}(238.9 \mu \mathrm{mol}$ $\mathrm{g}^{-1}$; Keiver et al. 1992), the initial liver glycogen content in the painted turtles in that study was twice $\left(647 \mu \mathrm{mol} \mathrm{g}^{-1}\right)$ that of the slider turtles in our study, so the fraction of the total liver glycogen consumed by sliders was much greater, approaching $83 \%$. Assuming that hepatic glycogen depletion continued at the same rate observed between 29 and $44 \mathrm{~d}, 100 \%$ depletion would have occurred by $64 \mathrm{~d}$. This, of course, also assumes that all tissue glycogen is capable of being mobilized.

The size of the liver glycogen store is particularly important for tissues that rely on liver-derived glucose during the anoxic submergence. This is the first study to document ventricular glycogen depletion during long-term anoxia at $3^{\circ} \mathrm{C}$ in any turtle species and shows that this tissue relied on liver-derived glucose after $13 \mathrm{~d}$, when its own glycogen was depleted. Although we did not measure brain glycogen in this study, other studies of red-eared sliders (Clark and Miller 1973) and painted turtles (Wasser et al. 1991) at warmer temperatures $\left(>20^{\circ} \mathrm{C}\right)$ have shown that it is low $\left(<1 \mathrm{mg} \mathrm{g}^{-1}\right)$ and that it changes little during anoxia. Therefore, it is probable that brain, like ventricle, was highly dependent on liver-derived glucose during submergence and would also be sensitive to reductions in its availability.

This is the first study of skeletal muscle glycogen depletion during long-term anoxic submergence in turtles at cold temperatures, so comparisons with painted turtles are limited. Skeletal muscle, which comprises about $20 \%$ of a turtle's body mass (Stecyk et al. 2004), appears to rely on liver-derived glucose after $29 \mathrm{~d}$, as indicated by the fact muscle glycogen contents changed little after that time. Not surprisingly, this correlated with the start of a decrease in plasma glucose at $44 \mathrm{~d}$. Increased extracellular glucose demands would serve to increase the rate of hepatic glycogen depletion and facilitate energy failure in heart and brain that rely on liver-derived glucose.

This study also showed that muscle glycogen depletion is not uniform and that pectoralis, the most commonly sampled muscle in studies of this kind because of its ventral location, is the least representative of the total muscle mass. Tissue glycogen did not decrease in this muscle until after $29 \mathrm{~d}$ of submergence, in contrast to the other sampled muscles, which fell steadily from the start of the submergence. We recommend that investigators sample multiple muscles in future studies of muscle metabolism in anoxic turtles to prevent any sampling bias.

It is possible that the condition of the turtles or the time of year at which the experiments were performed could have affected tissue glycogen and thus survival time. The control glycogen contents for heart and muscle from this study, taken in March and April, are generally similar to those from normoxic turtles between May and September (D. E. Warren and D. C. Jackson, unpublished data). Liver glycogen content from con- 
trol turtles in this study (279-299 $\left.\mu \mathrm{mol} \mathrm{g}^{-1}\right)$ were slightly lower than at these other times of the year $\left(406-589 \mu \mathrm{mol} \mathrm{g}^{-1}\right)$. The previous study of red-eared slider mortality during long-term anoxic submergence, in which $100 \%$ mortality occurred in less than $41 \mathrm{~d}$, was performed in November (Ultsch 1985).

The plasma ion changes during anoxia were qualitatively similar to those in painted turtles in some ways but different in others. Compared with the painted turtle after a comparable submergence period (Jackson et al. 2000), plasma $\mathrm{Cl}^{-}$decreased by a similar magnitude, plasma $\mathrm{Na}^{+}$changed less, and plasma $\mathrm{K}^{+}$increased at twice the rate. Hyperkalemia during anoxic submergence is probably caused by a global reduction in the efficiency of the $\mathrm{Na}^{+} / \mathrm{K}^{+}$ATPase in response to anoxia (Krumschnabel et al. 1996) and by intracellular acidosis (Sejersted and Sjogaard 2000). Anoxia coupled with hyperkalemia $\left(10 \mathrm{mmol} \mathrm{L}^{-1}\right)$ causes an $86 \%$ reduction in twitch force in vitro in red-eared slider turtle cardiac muscle strips, an effect alleviated by adrenergic stimulation (Nielsen and Gesser 2001). The importance of the hyperkalemia is difficult to ascertain because plasma $\mathrm{K}^{+}$was less than $10 \mathrm{mmol} \mathrm{L}^{-1}$ in our study and catecholamines are known to be elevated in submerged painted turtles at $3^{\circ} \mathrm{C}$ (Wasser and Jackson 1991). The hyperkalemia, however, might have contributed to the flaccid state observed in the submerged turtles after $44 \mathrm{~d}$. The absence of any change in plasma $\mathrm{P}_{\mathrm{i}}$ is consistent with the hypothesis that carbonate, not phosphate, is the major anion associated with bone buffering in turtles (Jackson et al. 1999).

In conclusion, the red-eared slider turtle's lower tolerance to anoxic submergence compared with painted turtles results chiefly from lower resting extracellular $\mathrm{HCO}_{3}^{-}$concentrations and blood $\mathrm{pH}$ and lower tissue glycogen contents, particularly in liver. There are no apparent differences between slider and painted turtles in their abilities to depress metabolic rate or in their capacities to buffer lactic acid with shell during long-term submergence. Future studies should examine whether the differences between these two closely related species result from evolutionary changes in the processes underlying tissue glycogen synthesis, such as glycogen synthase function, and renal $\mathrm{HCO}_{3}^{-}$reabsorption.

\section{Acknowledgments}

The study was supported by a National Science Foundation grant (IBN 01-10322) to D.C.J. We wish to thank Adeeb Rahman and Roland Remenyi for help with various aspects of this study.

\section{Literature Cited}

Clark V.M. and A.T. Miller Jr. 1973. Studies on anaerobic metabolism in the fresh-water turtle (Pseudemys scripta elegans). Comp Biochem Physiol 44A:55-62.
Conant R. and J.T. Collins. 1998. A Field Guide to Reptiles and Amphibians: Eastern and Central North America. Houghton Mifflin, Boston.

Herbert C.V. and D.C. Jackson. 1985. Temperature effects on the responses to prolonged submergence in the turtle Chrysemys picta bellii. I. Blood acid-base and ionic changes during and following anoxic submergence. Physiol Zool 58:655-669.

Hochachka P.W. 1986. Defense strategies against hypoxia and hypothermia. Science 231:234-241.

Jackson D.C. $2000 a$. How a turtle's shell helps it survive prolonged anoxic acidosis. News Physiol Sci 15:181-185.

. 2000b. Living without oxygen: lessons from the freshwater turtle. Comp Biochem Physiol 125A:299-315.

- 2002. Hibernating without oxygen: physiological adaptations of the painted turtle. J Physiol 543:731-737.

Jackson D.C., C.E. Crocker, and G.R. Ultsch. 2000. Bone and shell contribution to lactic acid buffering of submerged turtles Chrysemys picta bellii at $3^{\circ} \mathrm{C}$. Am J Physiol 278:R1564R1571.

Jackson D.C., Z. Goldberger, S. Visuri, and R.N. Armstrong. 1999. Ionic exchanges of turtle shell in vitro and their relevance to shell function in the anoxic turtle. J Exp Biol 202: 513-520.

Jackson D.C. and N. Heisler. 1983. Intracellular and extracellular acid-base and electrolyte status of submerged anoxic turtles at $3^{\circ} \mathrm{C}$. Respir Physiol 53:187-201.

Keiver K.M., J. Weinberg, and P.W. Hochachka. 1992. Roles of catecholamines and corticosterone during anoxia and recovery at $5^{\circ} \mathrm{C}$ in turtles. Am J Physiol 263:R770-R774.

Keppler D. and K. Decker. 1974. Glycogen determination with amyloglucosidase. Pp. 1127-1131 in H.U. Bergmeyer, ed. Enzymatic Analysis. Vol. 3. Academic Press, New York.

Krumschnabel G., C. Biasi, P.J. Schwarzbaum, and W. Wieser. 1996. Membrane-metabolic coupling and ion homeostasis in anoxia-tolerant and anoxia-intolerant hepatocytes. Am J Physiol 270:R614-R620.

Nielsen J. and H. Gesser. 2001. Effects of high extracellular $\left[\mathrm{K}^{+}\right]$ and adrenaline on force development, relaxation and membrane potential in cardiac muscle from freshwater turtle and rainbow trout. J Exp Biol 204:261-268.

Reese S.A., C.E. Crocker, D.C. Jackson, and G.R. Ultsch. 2000. The physiology of hibernation among painted turtles: the midland painted turtle (Chrysemys picta marginata). Respir Physiol 124:43-50.

Reese S.A., E.R. Stewart, C.E. Crocker, D.C. Jackson, and G.R. Ultsch. 2004. Geographic variation of the physiological response to overwintering in the painted turtle (Chrysemys picta). Physiol Biochem Zool 77:619-630.

Reeves R.B. 1976. Temperature-induced changes in blood acidbase status: $\mathrm{pH}$ and $\mathrm{PCO}_{2}$ in a binary buffer. J Appl Physiol 40:752-761. 
Sejersted O.M. and G. Sjogaard. 2000. Dynamics and consequences of potassium shifts in skeletal muscle and heart during exercise. Physiol Rev 80:1411-1481.

Stecyk J.A., J. Overgaard, A.P. Farrell, and T. Wang. 2004. Alphaadrenergic regulation of systemic peripheral resistance and blood flow distribution in the turtle Trachemys scripta during anoxic submergence at $5^{\circ} \mathrm{C}$ and $21^{\circ} \mathrm{C}$. J Exp Biol 207:269283.

Ultsch G.R. 1985. The viability of nearctic freshwater turtles submerged in anoxia and normoxia at 3 and $10^{\circ} \mathrm{C}$. Comp Biochem Physiol 81A:607-611.
Ultsch G.R. and D.C. Jackson. 1982. Long-term submergence at $3^{\circ} \mathrm{C}$ of the turtle Chrysemys picta bellii in normoxic and severely hypoxic water. I. Survival, gas exchange and acidbase status. J Exp Biol 96:11-28.

Wasser J.S. and D.C. Jackson. 1991. Effects of anoxia and graded acidosis on the levels of circulating catecholamines in turtles. Respir Physiol 84:363-377.

Wasser J.S., S.J. Warburton, and D.C. Jackson. 1991. Extracellular and intracellular acid-base effects of submergence anoxia and nitrogen breathing in turtles. Respir Physiol 83: 239-252. 
Copyright of Physiological \& Biochemical Zoology is the property of University of Chicago Press and its content may not be copied or emailed to multiple sites or posted to a listserv without the copyright holder's express written permission. However, users may print, download, or email articles for individual use. 